DA MATTA, R. O que faz o brasil, Brasil? Rio de Janeiro, Editora Rocco, 2a edição, 1986. 126 p.

Este é um livro curto e bem-humorado, cheio de figuras, as bem-sacadas ilustrações de Jimmy Scott. Daqueles livros que podem ser saboreados numa rede, sem nenhum outro compromisso além do de nos reconhecermos como os brasileiros de que fala Da Matta.

É também um livro interessante para nossos amigos estrangeiros que, por mais que se esforcem, não conseguem decifrar o código que pauta 0 comportamento dos brasileiros. Norteamericanos e europeus que aqui chegam, após um certo período de adaptação, em que se sentem inconformados por serem os únicos a observar horários, regras de trânsito etc., resolvem se aclimatar e abandonar toda e qualquer regra, o que os transforma nos maiores cometedores de gafe.

Entrando no clima do livro e, com o devido respeito que este autor merece, creio que ninguém melhor do que Da Matta para desempenhar, como antropólogo e autor, o protótipo do brasileiro que ele mesmo caracteriza. Explico-me:

O que faz o brasil, Brasil? é um livro tipicamente malandro. Com um objetivo pretensioso como o que $\mathrm{Da}$ Matta se propõe, traçar, a partir de uma leitura do Brasil, a nossa identidade, a do "Brasil que designa um povo, uma nação, um conjunto de valores, escolhas e ideais de vida" (p.11), o autor fica, certamente, numa situação diff́cil.
Da Matta é, entretanto, um autor reconhecidamente talentoso, que se utiliza com facilidade de expedientes e histórias (tal como o malandro que ele descrevel para se comunicar com - leitor. Como malandro talentoso, Da Matta tira bom partido da antropologia, e é este talento que permite levar a visão específica da disciplina para fora dos muros rigorosos da academia (onde ele é, talvez, mais aplaudido).

Através dos artifícios da malandragem, que, como o próprio autor define, "promove uma esperanca de tudo juntar, numa totalidade harmoniosa $e$ concreta" (p. 105), Da Matta busca uma leitura do Brasil, o que, convenhamos, não é tarefa fácil.

Mas Da Matta não parte do zero. Ele aqui retoma temas que já desenvolveu em trabalhos anteriores, desta vez enfatizando ainda mais a utilização "de uma antropologia com destemor e que proporciona uma visão da sociedade aberta e relativizada pela comparação" (p. 13).

Os capítulos do livro são os temas das nossas conversas de brasileiros: o carnaval, as relações marcadas pela hierarquia e negação do preconceito racial, o trabalho (associado à rua) e as relações familiares na casa; a malandragem e o jeitinho; promessas, padrinhos, milagres e outros temas característicos da junção que fazemos entre religião oficial e religiões populares.

As festas da ordem, sejam aquelas promovidas pelo Exército, ou pela Igreja, são o contraponto necessário 
à utopia vivida no carnaval. Onze páginas são imparcialmente dedicadas a cada um destes momentos las festas da ordem e as festas da desordem) que "servem como as verdadeiras roupagens pelas quais a sociedade cria $e$ recria sua identidade social e suas tradições" (p. 71).

Como o autor é homem e, além disso, brasileiro (carioca, ainda por cima) não poderia deixar de dedicar um capítulo a um tópico muito caro às conversas masculinas: mulheres $\mathrm{e}$ sua associação com as comidas que eles comem, tema que, ele não diz, mas é sabidamente carne-de-vaca nas mesas de bar que reúnem homens de mangas arregaçadas e colarinhos frouxos, após o trabalho.
No retrato que Da Matta faz dele próprio, ao final do livro, diz ter certeza de que ". a Antropologia Social é também um código literário e que só nos faltam a ousadia temática $e$ aquelá capacidade de observação $e$ articulação. " (p.125).

O que faz o brasil, Brasil? é, em vários sentidos, uma ousadia temática. Da Matta já teve uma experiência na televisão. Aguardamos para breve os seus romances, gênero que já se mostrou como um veio fecundo para os antropólogos brasileiros.

Sylvia Caiuby Novaes

Professora de Antropologia no Departamento de Ciências Sociais da FFLCH da Universidade de São Paulo

\section{ANTROPOLOGIA URBANA}

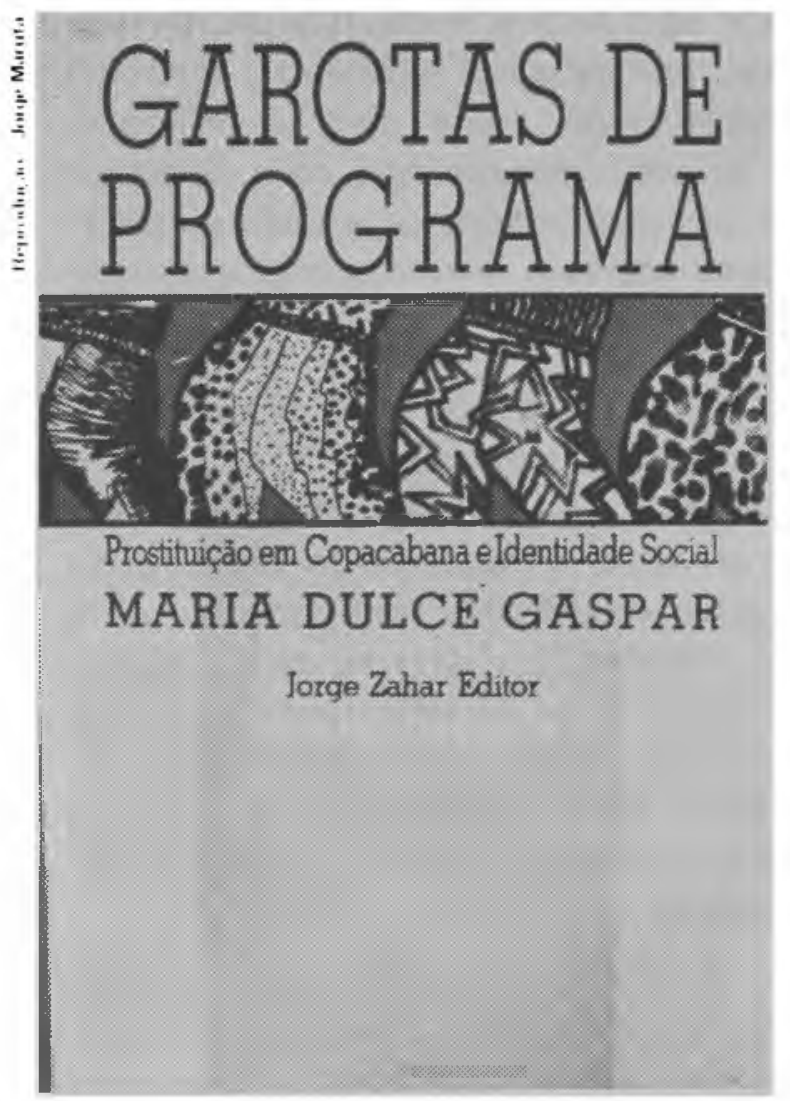

GASPAR, M. D. Garotas de programa: prostituição em Copacabana e identidade social. Rio de Janeiro, Jorge Zahar Editor, 1985. 135 p.

Resultado de uma dissertação de mestrado apresentada no Programa de Pós-Graduação em Antropologia Social do Museu Nacional em 1984, Garotas de Programa é uma boa contribuição para a antropologia urbana. Como diz a autora, na introdução da obra:

"O objetivo deste livro é entender a organização social e o sistema de representações de um certo tipo de prostituição praticado em algumas boates de Copacabana por mulheres jovens, oriundas de camadas médias, conhecidas como garotas de programa" (p. 11). 